\section{Hospital accreditation in Latin America}

\author{
Humberto M. Novaes ${ }^{1}$ \\ and Duncan Neuhauser ${ }^{2}$
}

The recession of the 1980s in Latin America resulted in the deterioration of the social sector and, therefore, hospitals. To remedy this situation and strive for an acceptable level of quality, in the 1990s many countries in Latin America began to implement hospital accreditation processes, with support from the Pan American Health Organization (PAHO) (1).

These Latin American efforts built on the successes in the United States of America of the Joint Commission on the Accreditation of Healthcare Organizations. This organization has worked since 1951 to improve the quality of health care in the United States. A number of other countries have established hospital accreditation systems, including Australia, Canada, Indonesia, and Thailand.

In Latin America and the Caribbean there are some 16000 hospitals, with a total of around one million beds. Nearly $70 \%$ of those hospitals have fewer than 70 beds each (2). Although Latin America has many prominent public and private medical centers comparable to the most advanced anywhere in the world, many other Latin American hospitals would not pass an evaluation review for a minimum level of quality. In addition, many Latin American hospitals have great variations in quality among their services. Fortunately, accreditation can often be achieved without major investments in infrastructure, which is an important consideration for the many nations in Latin America carrying heavy loads of foreign and internal debt.

\section{THE LATIN AMERICAN ACCREDITATION MODEL}

A major step toward creating a hospital accreditation model for Latin America took place with the I Latin America Conference on Hospital Accreditation, held in Washington, D.C., in 1989, with the participation of almost all the countries of Latin America. The conference representatives concluded that no country in Latin America was using hospital accreditation as a way to improve hospital quality (1).

In response, PAHO staff members and outside experts prepared a manual entitled the "Manual of Hospital Accreditation" and presented it in 1992 at the II Latin America Conference on Hospital Accreditation (3). Since then, the manual has served as a basic reference for many Latin American nations. Rather than being a set of requirements for 
each country to follow, the manual is intended to serve as an illustrative guide, with standards that are flexible and that can be adapted to allow for differences between one country and another.

The PAHO accreditation manual describes minimum quality standards for 37 hospital services, including ambulatory care and laboratory, nursing, and other basic hospital services, as well as the methodology for an outside team of surveyors to monitor compliance with these standards. The team of surveyors consists of at least three members: a physician, a nurse, and a hospital administrator. The surveyors, in turn, are appointed by a national hospital accreditation commission that each country establishes.

Following the initial launching of this accreditation effort, a series of national and subregional meetings were held to present and clarify the methodology in the new PAHO accreditation manual (4-7). During the meetings, the quality standards were analyzed and discussed extensively. Results of national hospital accreditation programs were presented in 1995, during the III Latin America Conference on Hospital Accreditation (8).

As each country in Latin America began the process of introducing and implementing hospital accreditation, a key step was to develop a national hospital accreditation manual based on the PAHO manual. This was done by convening a group of two or three specialists in hospital management to devise standards, and qualitative indicators for these standards, for each of the units of a general community hospital. These groups consulted scientific organizations and other specialists at the national level to adapt the PAHO manual to local realities. The new document was thoroughly reviewed by national experts and further adaptations were made as needed.

All the standards presented in the PAHO accreditation manual are organized by increasing and related degrees of complexity or of quality performance. "Level One," for example, contains guidelines on the credentialing of physicians and clinical staff and on the basic structures for quality care, including human and material resources. "Level Two" requires compliance with the Level One standards and also requires documented and applied standards, processes, and procedures; evidence of the introduction of a mechanism to improve care and medical processes; and evidence of patient-centered care. "Level Three" requires compliance with the first two levels and also evidence of improvement in all areas, a system to monitor satisfaction with in-hospital and outpatient care, and an effective hospital quality and productivity program.

This approach emphasizes progressive quality improvement in all services and highlights the fact that hospital structures and processes are so intertwined that the operation of one service affects all others and impacts the final outcomes. For example, a hospital may perform complicated clinical procedures, but its surgical center may have to halt work because of a lack of clean linens. Therefore, it is necessary that all of the hospital's services, from the laundry to the intensive care unit, reach at least the basic-level standard in order for the hospital to be accredited and receive the public recognition that accreditation brings.

To attain a higher level of quality for a specified hospital service, the standards for lower levels have to be satisfied first. Achieving the higher standards is a long-term goal. Within a single hospital, the standards evaluate aspects of structure, process, and outcomes through qualitative and dynamic evidence of performance or through indicators that reflect the quality of services provided, as proposed by Donabedian (9).

Outside surveyors conduct a data collection process to observe the qualitative indicators of compliance with the standards. This process must be kept as simple as possible. The results should offer information that persons in decision-making or managerial positions can use to make necessary changes.

Later, once a hospital has reached satisfactory compliance thresholds with the standards of structure and process, hospital staff can implement a quantitative data collection system for all hospital services. Such data could include average length of stay, cesarean section rates, and mortality rates. With these quantitative measures, hospital staff and outside accreditation surveyors can assess the outcomes and impact of medical care.

\section{Commitment of country-level leadership}

A commitment by national health care leaders is an essential element in developing a hospital accreditation system. With PAHO support, national health care experts must explain the methodology and operative rules of the accreditation process to these leaders, as well as how to organize a national accreditation commission. Such a commission should be multi-institutional, with representation from the ministry of health, social security, and the private sector.

Meetings of national health care experts with local health care leaders should also be held to explain the technical basis of the PAHO manual, including its aims, methodology, and format. Such discussions should also cover how a national accreditation manual will be used by hospital staff for hospital self-assessment, how external surveyors carry out their evaluations, and how the national ac- 
creditation commission takes the surveyors' recommendations and makes an accreditation decision.

\section{Initiation of accreditation}

Accreditation is periodic and confidential and establishes deadlines for correcting the flaws found in a hospital. Accreditation is thus a process of permanent education for hospital management.

One of the subjects discussed at many of the national meetings on hospital accreditation between 1989 and 1995 was the desired profile of surveyors, who would assess hospital functioning through visits lasting several days. At these national meetings, the representatives agreed that the surveyors should be professionals of unquestionable prestige and who have both clinical and administrative experience.

Physicians in Latin America, as in other countries, frequently use implicit, subjective criteria to judge the quality of medical care. In addition to implementing the hospital accreditation process, each hospital can develop its own explicit criteria and clinical guidelines to guarantee quality. Such criteria might include, for example, that a diagnosis of streptococcus be confirmed by microbiological culture before antibiotic therapy be used, or the necessary clinical steps to treat a heart attack in an emergency service. These explicit criteria, also known as clinical guidelines or protocols, indicate to the hospital accreditation surveyors that the hospital is fully committed to quality assurance.

\section{Application of standards for hospital accreditation}

Accreditation programs contribute to a planned and progressive change in habits. Hospital administrators can establish a hospital quality committee that analyzes recommended standards and verifies compliance with them. Clear goals can prompt hospital professionals in all units and services to evaluate their institution's strengths and weaknesses. Before, during, and after a hospital accreditation evaluation, hospital administrators must identify discrepancies between current practices and acceptable standards of quality, and the administrators must also find ways to reward persons who bring forward problems and present appropriate solutions.

Accreditation should precede any other initiative for evaluating quality, including such so-called efforts as "total quality" or "continuous quality monitoring" or the standards established by the International Standardization Organization (11-13).

\section{Establishment of a national commission}

During many of the last decade's PAHOsponsored meetings on hospital accreditation in the various countries of Latin America, a series of recommendation emerged for setting up national hospital accreditation commissions (14). The best of these suggestions always included the involvement of representatives of three groups: 1) hospitals, other health care providers, and hospital associations, with technical support from other medical and nonmedical professional associations, 2) buyers and users of health services, such as health maintenance organizations and private health insurance companies, and 3) the public sector, especially the ministry of health and ministry of social security.

Nurses will also be a vital part of this entire process. Out of all the professional groups who work in hospitals in Latin America, nurses are the only ones who are present at all times. Many physicians have two or three different jobs, and administrators work on a fixed schedule. Many nurses in Latin America have learned managerial and clinical auditing concepts and have unique skills to help in the assessment, implementation, and monitoring of the entire hospital accreditation process, including the establishment of a national hospital accreditation commission.

\section{THE EXAMPLE OF HOSPITAL ACCREDITATION IN BRAZIL}

Brazil represents an interesting case study of the hospital accreditation process in Latin America, if for no other reason than the large number of hospitals in the country, more than 6000 , with 400000 beds.

Representatives from Brazil participated in the I Latin America Conference on Hospital Accreditation in Washington, D.C., in 1989, and major steps forward were also taken at an accreditation seminar that PAHO organized and held in Brasília, Brazil, in 1992 (15).

In the mid-1990s independent accreditation initiatives were implemented in four states of Brazil. The first, in São Paulo, was developed by the São Paulo Association of Medicine and the Regional Board of Medicine. The second, in Rio Grande do Sul, was led by the private sector through its Hospital Association Program. The third, in Paraná, was started by the State Health Department. The fourth, in Rio de Janeiro, involved a joint effort of the National Academy of Medicine, the Brazilian College of Surgery, and the Institute for Social Medicine of the State University of Rio de Janeiro. 
In March 1997 the President and the Minister of Health of Brazil together launched a program entitled "1997/98 - The Year of Health in Brazil." This effort included a formidable array of high-priority government policy directives, actions, and goals to improve the quality of health services. The Ministry of Health proposed coordinating the process of evaluating the quality of client care in public and private hospitals through an initiative known as acreditação de hospitais (hospital accreditation). By introducing this phrase into Brazil with the same meaning as in other countries, it inspired public confidence. This proposal seeks to consolidate the different state initiatives, so that they use common criteria to evaluate hospital quality.

With support from the Ministry of Health a task-oriented multidisciplinary team was established in 1998 with representation from all the institutions that had been involved in the four states' accreditation efforts. The goal was to review the existing standards and to develop a new set of standards that would be acceptable to all parties and that could be applied in all the hospitals of Brazil. Also in 1998 the Ministry of Health implemented a pilot study in hospitals of different sizes and complexity and published 14000 copies of a first edition of a Brazilian manual of hospital accreditation.

In November 1998 the Ministry of Health approved a proposal for a national hospital accreditation commission, called the National Accreditation Organization. The new entity has a board of directors with representation from three general categories: 1) private hospitals, hospital associations, university hospitals, and charitable or religious hospitals, 2) health maintenance organizations, insurance companies, medical cooperatives, and other private sector organizations, and 3) the public sector, including the Ministry of Health and state and municipal health secretariats. In the future, this board's work will be supplemented by an ad hoc consultative committee that will have representation from medical associations, nurses associations, and other associations of health professionals, as well as from academic organizations. The ad hoc committee will support the national accreditation organization with ongoing recommendations for improving and updating standards and with new training materials for hospital administrators.

Funding for the National Organization on Accreditation is expected to come from the Ministry of Health, health service providers, and other sources. This diversity in financing sources will ensure the sustainability and political independence of the new commission.

Future efforts in Brazil will take place at both the national and state level. One goal will be to create a permanent national accreditation process. Another objective is to implement accreditation programs in more of the individual states, with the national accreditation organization creating nationwide standards and certifying the state entities that, in turn, will survey and accredit the individual hospitals.

During 1999 the Ministry of Health held 24 dissemination workshops in state capitals, with the participation of over 5500 person, including hospital administrators, state and municipal health service managers, and health sector professionals. The eventual goal in Brazil is to accredit hospitals at three progressive levels: accredited (reliable and organized), fully accredited (reliable, organized, with quality practices), and accredited with excellence (reliable, organized, with quality practices, and emphasizing standards of outcome).

\section{CONCLUSIONS}

A majority of the countries of Latin America and the Caribbean held national meetings and began to implement the accreditation process after the II Conference on Hospital Accreditation, in 1992. At the III Conference on Hospital Accreditation, held at the end of 1995, the various countries discussed the progress they had made, as well as future goals. Table 1 summarizes the progress that various countries in Latin America have made so far in the hospital accreditation process.

From those meetings and other experiences, a number of valuable lessons concerning accreditation have been learned. One lesson is that strong leadership is essential for the accreditation process to succeed. In Guatemala, for example, the leadership came from the private sector, while in Peru it came from the public sector. In some countries leadership was shared between the health ministry or other public sector agencies and private hospital associations or other private sector entities. This was the case in the Dominican Republic.

A country's national accreditation commission should be multi-institutional and broadly represent both the public and the private sectors. The presence of the ministry of health is essential because of its prestige and its ability to transfer resources within the national hospital system. Participation by the social security administration and private health insurers is also vital for implementation.

While they are important and useful, such instruments as executive orders, laws, and ministry of health regulations are not the paramount factor in promoting accreditation. In some cases, a new health minister has taken office and hindered the implementation efforts begun by a predecessor.

Surveyors assessing a hospital should not assign points or give a precise numerical score. Such 
TABLE 1. Progress on hospital accreditation made by 19 countries in Latin America, as of December 1998

\begin{tabular}{|c|c|c|c|c|}
\hline Country & $\begin{array}{c}\text { Initiation of } \\
\text { hospital accreditation }\end{array}$ & $\begin{array}{c}\text { Manual of } \\
\text { standards developed }\end{array}$ & $\begin{array}{c}\text { National } \\
\text { commission established }\end{array}$ & Implementation \\
\hline Argentina & Yes & Yes & Yes & Limited \\
\hline Bolivia & Yes & Yes & No & No \\
\hline Brazil & Yes & Yes & Yes & Yes \\
\hline Chile & Yes & Yes & No & Yes in public hospitals \\
\hline Colombia & Yes & Yes & No & On standby \\
\hline Costa Rica & No & No & No & No \\
\hline Cuba & Yes & Yes & Yes & Yes \\
\hline Dominican Republic & Yes & Yes & Yes & Yes \\
\hline Ecuador & No & No & No & No \\
\hline El Salvador & No & No & No & No \\
\hline Guatemala & Yes & Yes & Yes & Yes \\
\hline Honduras & No & No & No & No \\
\hline Mexico & Yes & Yes & No & No \\
\hline Nicaragua & Yes & Yes & No & Limited \\
\hline Panama & No & No & No & No \\
\hline Paraguay & Yes & No & No & No \\
\hline Peru & Yes & Yes & Yes & Yes \\
\hline Uruguay & Yes & Yes & Yes & Limited \\
\hline Venezuela & No & No & No & No \\
\hline Total "yes" number & 13 & 12 & 7 & 6 \\
\hline Total "yes" percentage & $68 \%$ & $63 \%$ & $37 \%$ & $32 \%$ \\
\hline
\end{tabular}

an approach can cause problems. For example, a point total may indicate an overall category of "excellent" or "good" while masking a hospital unit or activity that has serious problems. Instead, at the end of their accreditation visit, the surveyors should reach a consensus and recommend either full accreditation or just partial accreditation if the hospital needs some additional time to correct deficiencies.

"Utilization indicators" should not be misused in the accreditation process. Such utilization indicators as "length of stay" or "occupancy rate" are not indicators of quality but are instead data that describe productivity or the use of services.

Accreditation should not be confused with or take the place of licensing or categorization, which are used for other purposes. Argentina, for example, classifies its hospitals by categories, where one hospital may perform a given procedure but others in the same region may not. Such categorization is usually done to rationalize the use of hospital services. If a country tries to use accreditation as a tool for licensing and categorization, the additional complexity renders accreditation impractical.

The appearance of multiple independent and/or autonomous accreditation entities can threaten the accreditation process, since these groups can compete against each other and apply different priorities and standards. A single national commission can promote uniformity by setting accreditation standards to be followed throughout the country.
The accreditation process must be viewed as an auxiliary and permanent educational activity for hospital staff, not as a bureaucratic inspection or a critical audit in search of persons to blame. Accreditation surveyors should be seen as specialized consultants helping the hospital to overcome its managerial and technical shortcomings.

An adequate hospital assessment team will generally include a physician recognized for his or her clinical skills, a nurse with extensive hospital experience, and an administrator with a solid background in hospitals. Most hospital administrators in Latin America are physicians, but while serving on a surveyor team they should leave the observation of the hospital's clinical side to the team physician.

The sustainability of a national accreditation program is a major challenge. Accreditation is voluntary for hospitals, so these institutions must have some incentive to participate in the accreditation process. In the United States, for example, accreditation is required for hospitals that wish to receive payments through Medicare or Medicaid, which are national publicly funded government health programs covering, respectively, persons over age 65 and the poor, blind, and disabled. A similar approach of requiring accreditation in order to receive government reimbursement might provide suitable incentives in Latin America.

Hospital accreditation in Latin America could have a strong impact on the quality of medical care in the years to come. The United States has more 
than 5000 accredited hospitals, making it the world's most advanced nation in terms of control of medical and hospital care. Even these controls, however, do not prevent the health care industry in the United States from being a target of legal actions for malpractice or negligence. Such lawsuits distort the entire quality assurance system and cause care providers to increasingly practice "defensive" medicine. In Latin America, implementing effective hospital accreditation systems could help avoid these kinds of punitive legal actions.

In the future in Latin America, accreditation could be used not only for hospitals, but for the entire health service network, at the primary, secondary, and tertiary levels. Health ministries now allocate funds to the local levels without instruments to verify accountability or to assess whether these resources are having a positive impact on health. Accreditation of the network of health services could help correct that shortcoming and also help nations to assess the use of financial resources allocated to municipalities as part of the government decentralization process occurring all over Latin America.

\section{SINOPSIS}

\section{Acreditación de hospitales en América Latina}

Durante la década de los 80 se produjo un notable deterioro de la infraestructura física y de la operatividad de los hospitales de América Latina como consecuencia de la crisis económica que sufrieron casi todos los países de la Región y de las políticas sanitarias que pusieron el énfasis en la prevención de las enfermedades y en la promoción de la salud, en detrimento de la asistencia hospitalaria. Como reacción a esta situación y con el apoyo de la Organización Panamericana de la Salud, muchos países de América Latina iniciaron en la década de los 90 esfuerzos para implementar la acreditación de los hospitales, con el fin de establecer estándares de calidad para todos los servicios de cuidados agudos de los hospitales generales. Durante la última década, diversos países de América Latina han hecho avances en la puesta en práctica de esos programas de acreditación. Este artículo presenta las lecciones aprendidas como resultado de esas experiencias y expone el caso de Brasil como ejemplo de los pasos más importantes que debe dar un país al planificar y poner en práctica un programa de acreditación de hospitales.

\section{REFERENCES}

1. Pan American Health Organization. Informe final: I Conferencia Regional de Acreditación de Hospitales. Washington, D.C.: PAHO; 1992.

2. Pan American Health Organization. Directorio latinoamericano y del Caribe de hospitales. Washington, D.C.: PAHO; 1999.

3. Paganini JM, Novaes HM. La garantía de calidad - acreditación de hospitales para América Latina y el Caribe. Washington, D.C.: Pan American Health Organization; 1992. (Public. HSD/SILOS No. 13 in the "Desarrollo y Fortalecimiento de los Sistemas Locales de Salud" series).

4. Pan American Health Organization. Informe final: Reunión Sub-Regional de Acreditación de Hospitales del Caribe de Habla Inglesa. Washington, D.C.: PAHO; 1992.

5. Pan American Health Organization. Informe final: Reunión Sub-Regional de
Acreditación de Hospitales. Cono Sur: Washington, D.C.; PAHO; 1995.

6. Pan American Health Organization. Informe final: Reunión Sub-Regional de Acreditación de Hospitales. SubRegión Andina. Washington, D.C.: PAHO; 1994.

7. Pan American Health Organization. Informe final: Reunión Sub-Regional de Acreditación de Hospitales. Sub-Región México, Caribe de Habla Hispánica y Centro América. Washington, D.C.: PAHO, 1994.

8. Pan American Health Organization. Informe final; III Conferencia Regional de Acreditación de Hospitales. Washington, D.C.: PAHO; 1995.

9. Donabedian, A. The definition of quality and approaches to its assessment. Ann Arbor, Michigan: Health Administration Press; 1980.

10. Pan American Health Organization. Informe final: II Conferencia Regional de
Acreditación de Hospitales. Washington, D.C.: PAHO; 1992.

11. Gilmore C, Novaes HM. Gerência da qualidade. Washington, D.C.: Pan American Health Organization; 1996. (PALTEX/UNI series, Volume III).

12. Novaes HM. Calidad total - nuevo recurso para los hospitales de América Latina: el ingeniero gerencial. Educ Med y Salud 1994;28(4):490-505.

13. Novaes HM. ¿Estarán preparados los hospitales latinoamericanos y del Caribe para la reingeniería? Educ Med y Salud 1995;29(3/4):27-45.

14. Novaes HM. Programas de garantía de calidad a través de la acreditación de hospitales en América Latina y el Caribe. Salud Publica Mex 1993;35(3): 248-258.

15. Pan American Health Organization. Informe final: I Reunión Nacional de Acreditación de Hospitales. Brasília, Brazil: PAHO; 1992. 